2020, Volume 14, International Conference Innovative Business Management \& Global Entrepreneurship (IBMAGE 2020), pages: 157-167 |

https://doi.org/10.18662/lumproc/ibmage2020/12

\section{The Importance of Military Management in Pandemic Crises Management}

\author{
Marius NITA', \\ Sorela-Maria PRUTEANU2
}

${ }^{1}$ Valahia University from Targoviste, Romania, meser.nita@yahoo.com

${ }^{2}$ Valahia University from Targoviste, Romania, sorelamariapruteanu@gmail.com
Abstract: The year 2020 began with the coronavirus pandemic, which led to one of the most tumultuous periods in recent history, sending the world economy into a crisis that is hard to estimate, with a steep drop in economic growth and a recession with grim prospects of a return to its original situation. We are talking about major social, economic and political challenges, with implications that will be very difficult to manage in terms of social life, health care, unemployment or economic development. The current context of the global crisis due to the coronavirus pandemic, the implicit transformations that have occurred in the management of public administration has required a change in the classical attitude towards crisis management and management, namely the adoption of a more complex and comprehensive one, which will give you a firm concern for the affected areas, by resorting, where necessary, to a military management to solve the crisis. Military leadership is a strong one, with special training, that makes it able to manage crisis situations, because we are talking about people who are used to making decisions in conditions of uncertainty and having insufficient information.

The document presented is a study that examines the role played by the military environment in the context of the coronavirus pandemic, given that it has generated a complex chain of socioeconomic effects, and the need to involve military capabilities is more than necessary, considering one of the mission of army is supporting the authorities during unexpected situations.

Keywords: military management, coronavirus pandemic, crisis management, public authorities.

How to cite: Nita, M., \& Pruteanu, S. -M. (2020). The Importance of Military Management in Pandemic Crises Management. In M. W. Staniewski, V. Vasile, \& A. Grigorescu (vol. ed.), Lumen Proceedings: Vol. 14. International Conference Innovative Business Management \& Global Entrepreneurship (IBMAGE 2020) (pp. 157-167). Iasi, Romania: LUMEN Publishing House.

https://doi.org/10.18662/lumproc/ibmage2020/12 


\section{Introduction}

Coronavirus pandemic is a major problem facing both developed and developing countries, posing a major shock to economic and social life, with implications that cannot be calculated very precisely. Already some scenarios are catching a gradual return to the initial situation have proved far too optimistic, most countries have started to revert to restrictive measures imposed during the pandemic [14].

The medical crisis caused by the coronavirus is not a new one, history giving us countless examples of this, but nevertheless, humanity was rather unprepared to fight the pandemic, and the scenario seems to be repeated [2]. Public authorities are unprepared, professional medical associations and specialists disagree on measures to combat the pandemic, manipulation or disinformation take shape, through social-media being provided with various conspiracy theories: the virus was produced in the laboratory by China as a bacteriological weapon, the virus was produced by farm companies for financial profits, there is a link between the virus and $5 \mathrm{G}$ technology, the virus was produced by the new world order/elite. All these manipulations, which have had a huge outlet among the population, were also added to the views of prominent political leaders such as Donald Trump or Boris Johnson, who downplayed the danger of virus infestations.

Public authorities have had major difficulties in managing this crisis, stocks are uncovered, supply chains are not working, hospitals are not ready, in various areas involved in the management of the organizational management crisis have proved to be flawed, hasty or uninspired decisions have been taken by the leadership of the institutions, communication from the authorities or professional associations has not always been the most appropriate [15].

It was thus necessary for the central authorities to declare the pandemic as a national security issue, and the decision was taken to adopt the state of emergency, so that urgent decisions could be taken under timerestrictive conditions, but also to involve institutions in the field of national security, public order and national security, which were given crisis-specific missions [10].

The necessity to involve the military in this crisis appeared as a normal requirement in such a situation, for several reasons that will be analyzed in this article and related to the notion of crisis, with its defining elements (emergence, evolution, measures for intervention, post-crisis measures), but also from the utility of the military permanently in the public service, even if the coronavirus pandemic is not the best example of resilience for the military [5]. 


\section{Problem statement}

The specialized literature offers us a series of approaches regarding the term crisis, starting from the evolution in time, up to the different elements of analysis that are considered in its definition, classification, or typology. If we keep talking about a crisis in the medical field, it must be said that the notion of crisis, krisis in Greek language, represented for doctors in antiquity the time when a disease underwent a radical change. Apparently, the elements of this notion are clear, we are talking about a sudden transition from a state of equilibrium to another of major imbalance, with unpredictable and difficult to manage effect [18]. The term crisis has taken on variable, even contradictory forms, starting from a first characteristic, that of unpredictable, surprising event, passing through that of intensity, respectively with a very large evolution of the analysis parameters and ending with that of visibility in the sense that it is publicized and is accompanied by image damage at the level of the organizations involved in its management.

At the organizational level, the crisis manifests itself in many areas of science, such as international relations, economics, medicine, economics, psychology, but the most important are those of sociology because any crisis is spilling over to society and management for that only managerially can a crisis be solved [19].

A first approach shows that, in general, crises have a genesis and a genealogy, which are not the role of hazard, but the result of a long period of apparent equilibrium, with accumulations of dysfunctions of any kind, defining the crisis "an accumulation of probable events at the level of a part or the organization as a whole and which may interrupt its present or future operations affecting individuals and communities on a physical, psychological and / or existential level" [17]. Other specialists believe that crises manifest signs of panic but also opportunities for organizations to reduce the risk of production or strengthening and evolve from incident to crisis, going through different stages in a linear manner [4]. In contradiction, other experts believe that crises are not preceded by information or warning signals, but they start differently and do not give alarm signals [7, p. 43].

Crisis management, as part of the management of the organization, has acquired a special importance and requires the adoption of measures aimed at reducing as much as possible the effects caused [1]. Thus, organizations of any kind must adopt an emergency plan, open, in the sense of the need for permanent updating, designed on the basis of scenarios based on experience and lessons learned from previous crises and to be anchored in the daily realities and particular situations of each institution or organization. In military terms, these plans are called contingency plans, take 
into account the most likely scenarios for a crisis and set out response measures.

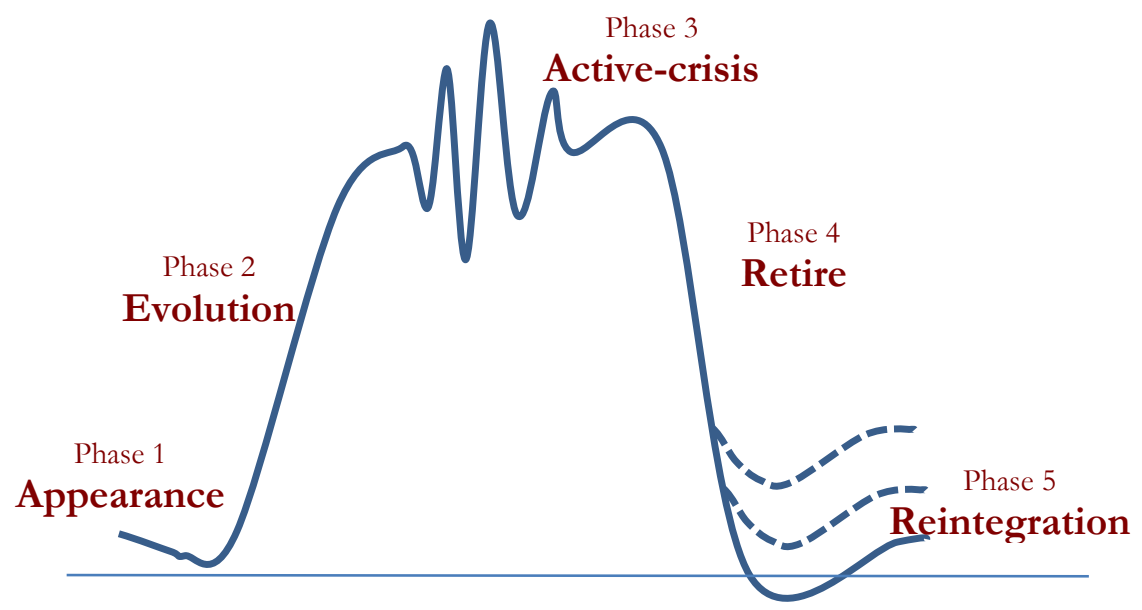

Figure no 1. Crisis evolution

Source: Author's conception

Recent research and debates define crisis situations as phenomena of interruption of the normal functioning of an organization, having as effects the occurrence of moments of blockage or dysfunctional organization of information exchange between the organization and its internal or external environment, and the end result is damage, both material and related to the prestige of the organization, by damaging the public image [3].

Depending on the areas of manifestation, several types of crisis can be identified, with the specific features of each, but there are some common defining elements for any type of crisis [20]:

- escalates quickly.

- the situation degenerates, confusion is created.

- requires rapid reaction measures.

- $\quad$ reveals some systemic problems.

- experimentation / innovation acquires a special importance.

- $\quad$ inadequate communication strategies are used.

\section{Research Questions/Aims of the research}

In this paper I will briefly argue the, the importance of military management during the coronavirus pandemic, how it can help public administration focused on identify solutions in organizations with managerial deficiencies or in critical situations and I will analyze the need to appeal to the army. 
The main objectives of my article are studying why military mast act in these situations and haw they can solve a crisis more efficiently than public authorities. It is a normal question, and we respond with some important arguments spring from the defining elements of the military environment.

The main objectives are to identify the difference between military and civil organization, briefly explain these and argue why it is important military involvement to act in crisis. To achieve the objectives of my study, the research methodology used in the development of this approach consists of documentation, descriptive and explanatory analysis of the specialized literature or opens sources, synthesis.

The purpose of this paper is to present the multidimensionality of the military organization by approaching it either from the perspective of the elements or values that make it up, or from its characteristics and functions, as they result from the studying it. As a consequence, interventions of army to support and help public institutions to manage crisis, acting responsible and quickly, promote the imagine of our army as a strong institution and the public service that can give it and, finally, citizens' trust.

\section{Research Methods}

To realize this article, I was used some methods of research and I started to build a knowledgebase, finding, and evaluating relevance information, properly collect, organize, retrieve and use literature, open sources and data. I explored the literature in this domain, I improved my reading comprehension about the topic by accessing authoritative, reliable and citable foundational information from books and reference works, available through innovative automated approaches for information extraction and relevancy ranking. All these offers me the flexibility in understanding the perceptions of experts in the field. A comprehensive overview of the military literature contributed to understanding the way of cations of the army. I continued to collect information through dialogs with colleges both managers or employers, in order to confirm some information, they had provided me. I managed information in order to obtain relevant information and ensure construct validity. For the research success, interpretation of results was based on observations, study and analyze, the significance of the data at the true meaning.

The results analysis provided a good understanding and offered empirical evidence, in order to generate own opinions on the need of military interventions and the importance of the military management during crisis. 


\section{Findings}

The army was called upon to intervene and support the efforts of authorities either at the strategic level by using its capabilities for strategic operations or the operational level using personnel and special techniques for punctual intervention in the affected areas [21].

Thus, several types of missions were carried out, which are presented below, with the mention that changes may occur at any time in function the measures taken to combat the pandemic:

- installation of three ROL 2 hospitals in Bucharest, Constanța and Timişoara.

- installation of epidemiological triage units in military and civilian hospitals.

- performing COVID-19 tests.

- ensuring the management of the hospitals from Suceava, Focsani, Deva.

- joint execution with police of patrol missions on compliance with the rules imposed by the authorities, of guarding some civilian objectives or control at the border points.

- air transport missions of medical equipment.

- on the line of research, the military has made a mass-produced isolate.

- food and hygiene packages were distributed to the elderly in the areas affected by coronavirus in Suceava.

- Romanian military specialists supported the effort of the authorities from the Republic of Moldova and the USA to manage the pandemic.

It is important to mention that the emergency intervention plans have been activated at the army and measures have been ordered at all organizational levels so that, if necessary, depending on the evolution of the situation, the army can intervene with all available resources to the support of the authorities, but in the conditions of continuation their missions [23]. 


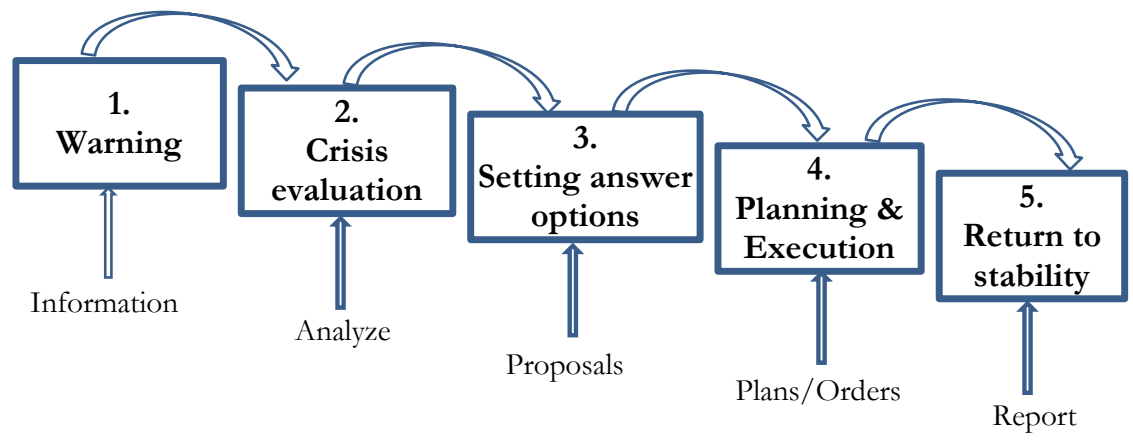

Figure no 2. Planning proces to manage a crisis

Source: Author's conception

\section{Discussions}

There was an urgent need for military intervention to support central and local authorities in combating the pandemic, because there were some critical moments and places when they were overtaken by the extent of the disease, and the situation could get out of control with much more complicated effects. It should also be mentioned that we are not talking about a classic emergency situation, more common such as intervention in floods, calamities, landslides, removal of the effects of weather or climate or a state of siege that would have involved the use of force [11].

We must analyse at how the military manages to overcome critical situations in much better conditions compared to the civilian [6, p. 105]. A first element that must be discussed is the organizational one, because the military organizations has a special specificity, which corresponds to both the general organizational purpose, the conduct of armed struggle and the operational goals that contribute to its achievement: continuous leadership, permanent information, uninterrupted support of all kinds or other specific activities [12].

A second element of analysis is the type of leadership, and in the military field, the leader is a strong person, trained to make decisions in conditions of uncertainty such as those during a crisis [8]. A firm leadership, subject to military rigor, capable to not give in to hardship and to inspire confidence among subordinate to follow him in all difficult actions is a solution at any time when the situation worsens [13].

Another element that we want to discuss is fundamental importance in the management of resources, both human and material, which is specific 
to the military environment. At all times, the human resource is mentally trained and prepared to deal with complex situations through unitary action, in a team and maintaining a high level of morale. Also, the military environment pays special attention to the management of material goods, and the concept of stocks is a common and permanent one in the current military activity. This is because the conflict is an area of uncertainty and unpredictability, therefore losses can occur at any time, requiring them to be supplemented with equipment from available reserve.

The last aspect that we want to bring to attention is that of internal procedures and rules, which determine the military to act firmly and rigorously, to manage responsibly the time resource or incomplete information, based on clear rules or hierarchically received orders [16]. One of its specific activities is the development of intervention scenarios in difficult conditions when times are quiet.

It must be borne in mind that the request for support from state institutions in crisis situations is not unprecedented, the military intervening in the event of natural or man-made disasters. Most countries also have similar legislation in national security, which allows the use of the armed forces to support public institutions in crisis or other non-military security components. For example, Switzerland is talking about the largest military mobilization after the Second World War, respectively up to 8,000 soldiers for types of actions to prevent and combat the pandemic, similarly to those of the Romanian military.

This study aimed to analyze synthetically the aspects underlying the need for military's intervention in a crisis situation, having as main elements of study the differences between the military and civilian environment, but did not take into account many other aspects of involvement military in combating the pandemic, such as those related to some legislative limitations, transfer of authority, use of funds, procurement procedures. Obviously, there are other elements that can be discussed, but we wanted to highlight those that we considered to be very important and defining in our study. Their approach could also be approached from other perspectives.

\section{Conclusions}

The coronavirus pandemic and the crisis that broke out is not a classic element specific to the military field, which would involve the use of weapons, but it proved that it could disrupt social life, becoming a security issue. The involvement of the military in such crises should not be considered a surprise, over de time periodically appearing situations when things can get complicated and the involvement of the armed forces 
becomes stringent, because it inevitably brings more professionalism specific to such situations, resulting from the defining elements of military environment, presented in this article [22]. During both vocational training and military training are trained in crisis management as a pre-armed conflict step, and crisis-specific elements, such as systemic organization or rapid decision-making in uncertain conditions, insufficient time resources or lack of resources are part of the military's current workload.

For a good management of it, a very good civil-military cooperation is essential, by involving all the actors with responsibilities in the complex field of security. In these crisis conditions, the decisions of all those involved in the management of this pandemic, whether we are talking about public authorities, firms, or people, take on particular importance. Everyone must work to identify and apply the best solutions in specific areas, the concentrated effort being the only way to overcome this complicated period, perhaps the worst in the last century [9].

From the way in which this pandemic unfolded and the measures adopted, it can be concluded that in order to manage a crisis, a comprehensive analysis and critical thinking is needed from all public institution, private and citizens, and the army, as a public organization with a special responsibilities, it also has a resistance component, for which it is constantly preparing and improving, in order to act in extreme situations to be of real help to the public service.

\section{References}

[1] Badea D. Cum se face managementul crizei în vremea COVID-19. 2020, 04; [cited 2020 Jul 15] Available from: https://www.forbes.ro/articles/managementul-crizei-vremea-covid-19$\underline{162342}$

[2] Bouzon A. Comunicarea în situații de criză. Bucureşti: Editura Tritonic. 2006. 313 p.

[3] Cavelty MD, Giroux J. CSS Analysis in Security Policy. Crisis Mapping: A Phenomenon and Tool in Emergencies, No 103, 2011. Avaible from:

[4] https://css.ethz.ch/en/publications/css-analyses-in-security-policy/cssanalyses-by-date $/$ details.html?id $=\% 2 \mathrm{Fn} \% 2 \mathrm{Fo} \% 2 \mathrm{~F} 1 \% 2 \mathrm{~F} 0 \% 2 \mathrm{Fno}$ 103 crisis mapping a phenomenon and $t$.

[5] Chiciudean I, Țoneş V., Gestionarea crizelor de imagine. ediţia a 2-a. Bucureşti: Editura Comunicare.ro. 2010. 234 p.

[6] Covey StR. Etica liderului eficient sau Conducerea bazata pe principii. Bucuresti: Editura ALLFA. 2001. 376 p. 
[7] Crăciun I. Prevenirea conflictelor şi managementul crizelor. Bucureşti: Editura Universității Naţionale de Apărare „Carol I”. 2006.

[8] Lagadec P. Preventing Chaos in a Crisis-Strategies for Prevention, Control and Damage Limitation. (Jocelyn M. Phelps, trad.). London: McGraw-Hill Book Company. 1993.

[9] Fulmer RM, Conger JA. Growing your company's leaders: How Great Organizations Use Succession Management to Sustain Competitive Advantage, New York, Ed. AMACOM. 2004.

[10] Grigorescu A, Olteanu LM. Change Management and the Economic Crisis. Ovidius University Annals Economic Sciences Series; 2012 May; 12(1):976981.

[11] Grigorescu A, Chițescu RI. Modern Leadership by Applying a CrisisAdjusted Management. Ovidius University Annals, Economic Sciences Series; 2012 Dec; 12(3): 1-47. Available from: https://ideas.repec.org/a/ovi/oviste/vxiiy2012i3p47.html

[12] Ghiba D. Studiu privind managementul crizelor politico-militare. Bucureşti: Editura Universității Naționale de Apărare „Carol I”. 2014; p. 51. Available from: https://ideas.repec.org/a/ovi/oviste/vxiiy2012i12p976-981.html

[13] Habian L, Telespan C. Managementul organizatiei militare - functiuni. Sibiu: Editura Academiei Fortelor Terestre. 2003.

[14] Heikkila AM, Havlik D, Schlobinski S. (editors). Modelling crisis management for improved action and preparedness. 2015. Helsinki. Julkaisija-Utgivare-Publisher. Available from: https://www.vttresearch.com Lsites/default/files/pdf/technology/2015/T228.pdf

[15] Harvard Business Review. Mcnulty EJ, Marcus L. Are You Leading Through the Crisis ... or Managing the Response?. 2020 March; Available from: https://hbr.org/2020/03/are-you-leading-through-the-crisis-or-managingthe-response

[16] Muresan M, Tenu C, Stăncilă L. Corelatia artei militare cu fenomenul militar contemporan, curs de arta militara. Bucuresti: Editura Universitatii Nationale de Apărare. 2005.

[17] Neagoe V. Elemente de teorie si constructie militara. Bucuresti: Editura Militara. 2005.

[18] Pearson CM, Roux-Dufort C, Clair JA. International Handbook of Organizational Crisis Management. Thousand Oaks: SAGE Publications Inc. 2007 Jan 1.354 pages. $10.4135 / 9781412982757$

[19] Petrisor M. Managementul crizelor. Braşov: Editura Univ. Transilvania. 2007. 
[20] Rosenthal U, Boin RA, Comfort LK. Managing Crises - Threats, Dilemmas, Opportunities. Springfield: Charles C Thomas Pub Ltd. 2001.

[21] Spariel C. Effective crisis management: Tools and best practice for the new millennium. Journal of Communication Management: October 2003.7(4):348-355. https://doi.org/10.1108/13632540310807485

[22] Statul Major al Apărării, Gândirea Militară Românească, no. 3, 2020. Available from:

https://gmr.mapn.ro/app/webroot/fileslib/upload/files/arhiva\%20GMR/ 2020\%20gmr/3\%202020\%20gmr/VLAD.pdf

[23] Virtual Speech. Thompson S. The Complete Guide to Crisis Management and Communication. 2018. Available from:

https://virtualspeech.com/blog/crisis-communications-and-managementguide

[24] Watkins MD, Bazerman HM. Predictable Surprises: The Disasters You Should Have Seen Coming. 2003. Available from:

https://hbr.org/2003/04/predictable-surprises-the-disasters-you-shouldhave-seen-coming. 